\title{
Electrochemical measurement of endogenously produced nitric oxide in brain slices using Nafion/o-phenylenediamine modified carbon fiber microelectrodes
}

\author{
Nuno R. Ferreira ${ }^{\mathrm{a}}$, Ana Ledo ${ }^{\mathrm{a}}$, João G. Frade ${ }^{\mathrm{a}}$, Greg A. Gerhardt ${ }^{\mathrm{b}}$, \\ João Laranjinha ${ }^{\mathrm{a}, \mathrm{c}}$, Rui M. Barbosa ${ }^{\mathrm{a}, \mathrm{d}, *}$ \\ ${ }^{a}$ Center for Neurosciences and Cell Biology, University of Coimbra, Coimbra, Portugal \\ ${ }^{\mathrm{b}}$ Department of Anatomy and Neurobiology, University of Kentucky, Lexington, KY 40356, USA \\ ${ }^{c}$ Laboratory of Biochemistry, Faculty of Pharmacy, University of Coimbra, Coimbra, Portugal \\ d Laboratory of Instrumental Analysis, Faculty of Pharmacy, University of Coimbra, Couraca dos Apostolos 51 r/c, 3000295 Coimbra, Portugal
}

Received 11 October 2004; received in revised form 8 December 2004; accepted 8 December 2004

Available online 18 January 2005

\begin{abstract}
The role of nitric oxide $\left({ }^{\bullet} \mathrm{NO}\right)$ as a regulatory diffusible molecule in the brain requires the evaluation of its concentration dynamics. In this work, we have developed microelectrodes suitable for real time electrochemical measurements of ${ }^{\bullet} \mathrm{NO}$ in vitro. Nafion and $o$-phenylenediamine were used to modify the surface of carbon fiber microelectrodes $\left(8 \mu \mathrm{m}\right.$ diameter; $\approx 100 \mu \mathrm{m}$ tip length). Coating with Nafion was done at $170{ }^{\circ} \mathrm{C}$ and the $o$-phenylenediamine solution was electropolimerized on the carbon surface. ${ }^{-\mathrm{NO}}$ peak potential $(+0.78 \pm 0.03 \mathrm{~V}$ versus $\mathrm{Ag} / \mathrm{AgCl})$ was determined by square wave voltammetry with $\bullet \mathrm{NO}$ solutions prepared from the-generating compound diethylenetriamine/nitric oxide (DETA/NO). Microelectrodes were calibrated by amperometry at a potential of $+0.90 \mathrm{~V}$ versus $\mathrm{Ag} / \mathrm{AgCl}$. They showed good sensitivity $(954 \pm 217 \mathrm{pA} / \mu \mathrm{M} ; n=6)$ and linearity to ${ }^{\bullet} \mathrm{NO}$ in the concentration range of $100-1000 \mathrm{nM}$. They were also characterized in terms of detection limit $(6 \pm 2 \mathrm{nM}, n=4)$, response time at $50 \%(1 \mathrm{~s})$, and selectivity against interferents, such as nitrite $(780 \pm 84: 1, n=6)$, ascorbic acid $(750 \pm 187: 1, n=6)$ or dopamine $(18 \pm 2: 1, n=6)$. Injections of $1 \mathrm{mM} \mathrm{L}$-glutamate, $1 \mathrm{mM}$ L-arginine, and $0.1 \mathrm{mM} N$-methyl-D-aspartate did not produce changes in background current. Finally, the microelectrodes were used to measure ${ }^{\bullet} \mathrm{NO}$ concentration dynamics in rat hippocampal brain slices stimulated with L-glutamate and $N$-methyl-D-aspartate. Taken together, the data indicate that the microelectrodes exhibit the proper sensitivity and selectivity for studies of ${ }^{\circ} \mathrm{NO}$ dynamics in brain slices (in vitro) and possibly in whole brain (in vivo) recordings.
\end{abstract}

(C) 2004 Elsevier B.V. All rights reserved.

Keywords: Nitric oxide; Microelectrode; Hippocampus; Nafion; $o$-Phenylenediamine

\section{Introduction}

Since the late $1980 \mathrm{~s}$, when the importance of ${ }^{\bullet} \mathrm{NO}$ in smooth muscle vasodilatation was discovered [1-3], there has been considerable research activity concerning the biological activity of ${ }^{\bullet} \mathrm{NO}$. In the brain, it has been shown to be involved in number of diverse functions, ranging from neurotransmission to neurodegeneration $[4,5]$. As a small and hydrophobic

\footnotetext{
* Corresponding author. Tel.: +351 239852563; fax: +351 239852569 .

E-mail address: rbarbosa@ff.uc.pt (R.M. Barbosa).
}

molecule, ${ }^{\bullet} \mathrm{NO}$ diffuses rapidly through biomembranes, being a convenient intercellular messenger. Thus, in the brain, it may act within the cell, where it was originated or diffuse to neighbouring cells linking the activities of neurons in a local volume of tissue regardless of synaptic connections [6].

A variety of methods for ${ }^{-N O}$ measurement are available involving spectrophotometry, chemiluminescence, mass spectrometry and electron paramagnetic resonance (EPR) [7-11]. Most of these approaches rely on the measurement of secondary and reaction products (e.g., nitrites and nitrates, Hemoglobin- $\mathrm{Fe}^{3+}$ and L-citrulline), and formation of stable 
adducts (e.g., Hemoglobin- $\mathrm{Fe}^{2+}-\mathrm{NO}$ and other NO-iron complexes) that require sample processing. They do not allow real time measurements of endogenous ${ }^{\bullet} \mathrm{NO}$ production in situ and provide complementary information that it is difficult to translate into the ${ }^{\bullet} \mathrm{NO}$ concentration dynamics in tissues.

The use of microelectrodes for electrochemical detection of ${ }^{\bullet} \mathrm{NO}$ in tissues makes real time measurements possible, due to the high temporal resolution. The small size of these microelectrodes $(0.5-35 \mu \mathrm{m}$ diameter) allow a high spatial resolution and makes them excellent sensors for direct placement into biological preparations without causing extensive damage to tissues [12-16].

There are two major types of surface-modified electrodes, which are suitable for the oxidative determination of $\bullet$ NO. The first type works by direct oxidation of ${ }^{\bullet} \mathrm{NO}$ at sufficiently high electrode potential using gas permeable membranes to enhance selectivity. The second type is based on the coating of the electrode surface with polymer modifiers. The combination of the deposited polymer film and a support constitutes a polymer-modified electrode, and these electrodes have better analytical properties, such as selectivity, sensitivity or stability. In fact, most of the described microelectrodes are based on a conventional two or three-polymer film design with each film performing specific tasks [16-18].

Briefly, the microelectrode consists of single carbon fiber electrodes coated with Nafion acting as a anionic filter [19,20] and electropolimerized with $o$-phenylenediamine $(o-\mathrm{PD})$, a polymer that works as a molecular filter, limiting the access of large molecules to the microelectrode surface [14]. The microelectrodes were applied in the measurement of ${ }^{\bullet} \mathrm{NO}$ dynamics following stimulation of hippocampal rat brain slices with L-glutamate and $N$-methyl-D-aspartate (NMDA).

The main goal of this work was to develop a microelectrode that could be sensitive to low nanomolar ${ }^{\bullet} \mathrm{NO}$ concentrations and would be selective against potential interferents in brain tissue in order to use them in rat hippocampal brain slices for the monitoring of ${ }^{\bullet} \mathrm{NO}$ dynamics.

\section{Experimental}

\subsection{Chemicals and solutions}

Diethylenetriamine/nitric oxide was used for preparing ${ }^{-N O}$ standard solutions and was supplied by Sigma (USA). Nitrite $\left(\mathrm{NO}_{2}{ }^{-}\right)$was used for selectivity studies and calibration of the ISO-NOP sensor. It was supplied by Riedel-de-Häen (Hannover, Germany). Nafion perfluorinated ion-exchange polymer $(5 \mathrm{wt} . \%$ solution in a mixture of lower aliphatic alcohols, Aldrich, USA) and $o$-PD (Fluka Chemica, Switzerland) was used for electrode surface modification. Tyrosine (Merck, Darmstadt, Germany), ascorbic acid (AA) (Fluka), hydrogen peroxide $\left(\mathrm{H}_{2} \mathrm{O}_{2}\right)$ (Merck, Darmstadt, Germany), dopamine (DA) (Fluka), 5-hydroxytryptamine (5-HT) (Sigma, St. Louis, MO, USA), L-glutamate (L-Glu)
(Biochemical), L-arginine (L-Arg) (Sigma, USA) and NMDA (Tocris Cookson Ltd., Avonmouth, UK) were used for selectivity studies. Peroxynitrite $\left(\mathrm{ONOO}^{-}\right)$was prepared by adding $\mathrm{NO}_{2}{ }^{-}$to an acidic solution of hydrogen peroxide. The reaction was quenched by addition of $\mathrm{NaOH}$ [21]. Chemicals used for buffer preparations were obtained from Sigma (USA). All the compounds were analytical grade or better and used as received.

The buffer solution used for analytical evaluation of microelectrode was phosphate-buffer saline (PBS), $\mathrm{pH} 7.4$ with the following composition (in $\mathrm{mM}$ ): $140 \mathrm{NaCl}, 7 \mathrm{KCl}, 8.1$ $\mathrm{Na}_{2} \mathrm{HPO}_{4}, 1.8 \mathrm{KH}_{2} \mathrm{PO}_{4}$, supplemented with $100 \mu \mathrm{M}$ diethylenetriaminepentacetic acid.

After isolation, hippocampal brain slices were recovered in artificial cerebrospinal fluid (aCSF) containing (in $\mathrm{mM}$ ): $124 \mathrm{NaCl}, 2 \mathrm{KCl}, 25 \mathrm{NaHCO}_{3}, 1.25 \mathrm{KH}_{2} \mathrm{PO}_{4}, 10 \mathrm{MgSO}_{4}, 0.5$ $\mathrm{CaCl}_{2}$, supplemented with $10 \mathrm{mM}$ glucose, $1 \mathrm{mM}$ glutathione (GSH) and $0.2 \mathrm{mM}$ ascorbate and they were constantly gassed with $95 \% \mathrm{O}_{2}$ and $5 \% \mathrm{CO}_{2}$ for a $\mathrm{pH}$ 7.4. During experiments, the slices were perfused with aCSF containing $1.5 \mathrm{mM} \mathrm{CaCl}_{2}$ without $\mathrm{GSH}$, ascorbate and $\mathrm{MgSO}_{4}$.

The stock solutions of DA and 5-HT were prepared in $1 \%$ perchloric acid, and were kept at $-18^{\circ} \mathrm{C}$.

The ${ }^{\bullet} \mathrm{NO}$ stock solution was prepared in a $10 \mathrm{mM} \mathrm{NaOH}$ solution achieving a final concentration of $10 \mathrm{mM}$ DETA/NO. The stock solution was kept at $-18^{\circ} \mathrm{C}$.

\subsection{Electrochemical instrumentation}

The concentration of ${ }^{\bullet} \mathrm{NO}$ released from DETA/NO was determined using the ISO-NOP $2 \mathrm{~mm}$ Pt sensor connected to the amperometer ISO-NO Mark II (World Precision Instruments Inc., USA) calibrated by chemical generation of ${ }^{\bullet} \mathrm{NO}$ from reaction of $\mathrm{NO}_{2}{ }^{-}$with an excess of iodide and sulphuric acid.

Fast cyclic voltammetry (FCV) was carried out with an EI400 potentiostat (Ensman Instruments, Bloomington, USA). Signals were monitored on a digital storage oscilloscope (Tektronix TDS 220, Portland, OR, USA).

Amperometric currents were measured using the PGSAT 12 (Eco Chemie, The Netherlands) potentiostat with low current module installed and controlled by GPES software version 4.9 in amperometric mode for testing microelectrodes and a nano-amperometer (Tacussel/Radiometer AMU130, France) for brain slices recordings. The working electrode was always held at a potential of $+0.9 \mathrm{~V}$ versus $\mathrm{Ag} / \mathrm{AgCl}$. FCV and amperometric recordings obtained with PGSAT 12 were performed in a three-electrode cell using a Pt-wire auxiliary electrode, a $\mathrm{Ag} / \mathrm{AgCl}(3 \mathrm{M})$ reference electrode and the carbon fiber microelectrode as working electrode.

\subsection{Preparation of nitric oxide microelectrodes}

Microelectrodes were fabricated as described [22,23]. Briefly, single carbon fibers ( $8 \mu \mathrm{m}$ i.d.; Courtaulds, Ltd., UK) were inserted into borosilicate glass capillaries $(1.16 \mathrm{~mm}$ 
i.d $\times 2.0$ mm o.d.; Harvard Apparatus Ltd., UK), cleaned with acetone at room temperature and pulled on a vertical puller (Harvard Apparatus Ltd., UK). The protruding carbon fibers were cut in order to obtain an exposed carbon surface with a tip length of ca. $100 \mu \mathrm{m}$ length. The electrical contact between the carbon fiber and the copper wire was provided by conductive silver paint (RS, UK).

\subsection{Microelectrode surface modification}

The microelectrodes were firstly coated with Nafion by dipping the carbon fibers into a Nafion solution (5\% in aliphatic alcohols) at room temperature for $30 \mathrm{~s}$ and drying for $10 \mathrm{~min}$ at $170^{\circ} \mathrm{C}$ in a drying oven. It has been shown that drying Nafion at high temperatures produces microelectrodes with improved recording properties [24]. In this work, microelectrodes with one coat of Nafion were used. The $o$-PD film was electrodeposited as previously described [14]. Briefly, a $5 \mathrm{mM} o$-PD solution in PBS supplemented with $100 \mu \mathrm{M}$ AA was made fresh and electropolimerized on the carbon fiber surface by amperometry at a constant potential of $+0.9 \mathrm{~V}$ versus $\mathrm{Ag} / \mathrm{AgCl}$ during $15 \mathrm{~min}$.

\subsection{Microelectrode testing procedures}

After fabrication, the microelectrodes were tested for general recording characteristics in PBS medium using FCV at $200 \mathrm{~V} / \mathrm{s}$ scan rate between -0.4 and $+1.6 \mathrm{~V}$. This potential range provides an electrical pre-treatment of the carbon fiber that improves electrode sensitivity. The stability of the background current and sharp transients at reversal potentials were used as indicators to accept a microelectrode with good recording properties [25].

The microelectrodes were calibrated by a single stream flow injection analysis system (FIA) using a home-made flow cell with aerated PBS as carrier solution at a flow rate of $2 \mathrm{~mL} / \mathrm{min}$. After a stable baseline was achieved, $100 \mu \mathrm{L}$ DETA/NO solution in deaerated PBS were injected repeatedly with a four-valve port and the transient currents were measured using a PGSAT 12 potentiostat in the amperometric mode. After injection, solution takes $3 \mathrm{~s}$ to reach the electrochemical detector, a lag time identical to that taken by a non-reactive analyte, such as dopamine. Oxygen tension in PBS carrier solutions did not decrease the signal amplitude.

Limit of detection (LOD) was calculated according to the formula $\mathrm{LOD}=3 \times \mathrm{S} . \mathrm{D} . / m$, where $m$ represents the slope of the calibration curve and S.D., the standard deviation of the regression line.

Selectivity ratios of the polymer coated microelectrodes were determined by comparing the change in current produced by $100 \mu \mathrm{M}$ DETA/NO with the current measured after injection of $100 \mu \mathrm{M} \mathrm{AA}, 100 \mu \mathrm{M} \mathrm{NO}_{2}{ }^{-}, 4 \mu \mathrm{M}$ DA, $4 \mu \mathrm{M}$ 5-HT, $1 \mathrm{mM}$ L-glutamate, $1 \mathrm{mM}$ L-arginine, $0.1 \mathrm{mM}$ NMDA, $10 \mu \mathrm{M}$ tyrosine, $200 \mu \mathrm{M} \mathrm{H}_{2} \mathrm{O}_{2}, 20 \mu \mathrm{M} \mathrm{N} \mathrm{O}_{y}$ and $100 \mu \mathrm{M}$ $\mathrm{ONOO}^{-}$.
The response time was determined amperometricaly in a flow stream of PBS at $2 \mathrm{~mL} / \mathrm{min}$ using a peristaltic pump and teflon tubing with a $0.8 \mathrm{~mm}$ diameter. The response time was calculated as the time to reach $50 \%$ of maximum current in response to single bolus injections of $26 \mu \mathrm{M}$ DETA/NO. Bare microelectrodes were used as control.

\subsection{Monitoring ${ }^{\bullet} \mathrm{NO}$ in brain slices}

Brain slices were obtained as previously described [23]. Briefly, the brains from 4- to 6-week-old male Wistar rats were rapidly removed and chilled in ice-cold aCSF medium, which was constantly bubbled with $95 \% \mathrm{O}_{2} / 5 \% \mathrm{CO}_{2}, \mathrm{pH} 7.4$. The two hippocampi were dissected out and placed on the stage of a Mcilwain tissue chopper. Sections $(400 \mu \mathrm{m}$ thickness) were cut and allowed to recover at room temperature in oxygenated aCSF for $1 \mathrm{~h}$ prior to experiments. The slices were then transferred to a full immersion chamber (Harvard, USA; $0.5 \mathrm{~mL}$ volume) superfused with $\operatorname{aCSF}\left(32^{\circ} \mathrm{C}\right)$ at a flow rate of $2 \mathrm{~mL} / \mathrm{min}$. In the case of NMDA stimulations, $\mathrm{Mg}^{2+}$ was removed form the perfusion medium.

The microelectrode tip was placed in the CA1 region of the hippocampus, $200 \mu \mathrm{m}$ deep into the slice, with the aid of a micromanipulator and a dissection microscope (Olympus, Japan). Once a stable background current was obtained, slices were challenged by perfusion during $2 \mathrm{~min}$ with either a $10 \mu \mathrm{M}$ NMDA solution or a $5 \mathrm{mM}$ L-glutamate solution.

\subsection{Data analysis}

Data are expressed as the mean \pm S.E.M. and were analysed for statistical significance defined at $P<0.05$ using a Student's $t$-test. Integral charge was calculated as the time integral of the amperometric current, after subtraction of the respective background current. Statistical analysis and integration were performed using commercially available software.

\section{Results and discussion}

\subsection{Measurement of ${ }^{\bullet} \mathrm{NO}$ release from $\mathrm{DETA} / \mathrm{NO}$}

The accuracy of ${ }^{\bullet} \mathrm{NO}$ concentration measurements relies on an accurate preparation of ${ }^{\circ} \mathrm{NO}$ standard solutions. Three procedures are commonly used for preparation of -NO standard solutions; chemical generation of ${ }^{\bullet} \mathrm{NO}$ from reaction of iodide with nitrite in acidic solution; bubbling - NO gas into deoxygenate aqueous solution until saturation; and decomposition of ${ }^{-N O}$-generating compounds. The chemical procedure routinely used for calibration of commercial sensors ISO-NOP (WPI) is not appropriate for microelectrodes because the extremely acidic solution causes damage to the microelectrode coatings. Thus, calibrations of -NO microelectrodes are usually performed from saturated 


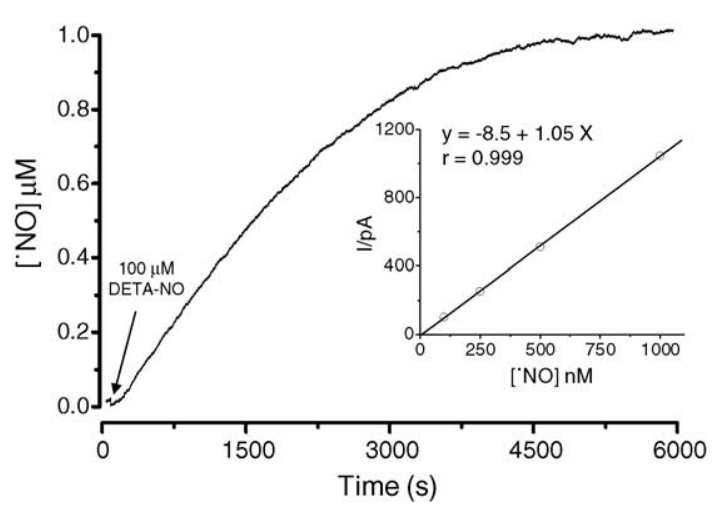

Fig. 1. Amperometric measurement of $\bullet \mathrm{NO}$ released upon addition of $100 \mu \mathrm{M} \mathrm{DETA} / \mathrm{NO}$ (arrow), a ${ }^{\bullet} \mathrm{NO}$-generating compound to a deoxygenated PBS solution. The current values, measured with ISO-NOP sensor (WPI), were converted to $\mathrm{NO}$ concentrations, according to the calibration curve (inset).

solutions of $\bullet \mathrm{NO}$ gas or alternatively from the $S$-nitrosothiol -NO-generating compound SNAP [16,26].

The diazeniumdiolates constitutes an alternative class of -NO-release compounds that have some advantages over $S$ nitrosothiols, particularly, a spontaneous and reproducible rate of ${ }^{\bullet} \mathrm{NO}$ generation in aqueous media. DETA/NO spontaneously releases ${ }^{\bullet} \mathrm{NO}$ at $\mathrm{pH} 7.4$ with a half-life of $52 \mathrm{~h}$ at $22{ }^{\circ} \mathrm{C}[27,28]$.

In this study, we have determined the rate of ${ }^{\bullet} \mathrm{NO}$ released from DETA/NO solution using the $2 \mathrm{~mm} \mathrm{Pt}{ }^{\bullet} \mathrm{NO}$ sensor (ISONOP). Fig. 1 shows the time course of spontaneous ${ }^{\bullet} \mathrm{NO}$ release after addition of $100 \mu \mathrm{M}$ DETA/NO to a deoxygenated PBS ( $\mathrm{pH}$ 7.4) solution at $22^{\circ} \mathrm{C}$. As can be observed, the current increased continuously and reached a steady-state value -NO concentration of $1 \mu \mathrm{M}$ after $1 \mathrm{~h}$. The ISO-NOP sensor was previously calibrated following the chemical procedure to determine accurately the ${ }^{\bullet} \mathrm{NO}$ concentration (inset).

\subsection{Characterization of the microelectrodes}

\subsubsection{Oxidation potential of $\bullet$ NO}

The electrochemical oxidation of ${ }^{\bullet} \mathrm{NO}$ on solid electrodes produces the nitrosonium cation $\left(\mathrm{NO}^{+}\right)$, which upon reaction with $\mathrm{OH}^{-}$in aqueous solutions yields $\mathrm{NO}_{2}{ }^{-}$that, in turn, is further oxidised to nitrate [29]. The oxidation potential depends on a significant number of factors, including surface composition, electrochemical pre-treatment of the solid support, chemical modifications of electrode surface and the electrochemical cell. In oxygenated saline solution, ${ }^{\bullet} \mathrm{NO}$ is rapidly oxidised to $\mathrm{NO}_{2}{ }^{-}$(half-life $0.5-15 \mathrm{~s}$ ) [20-32]. Such a short half-life and the fact that $\mathrm{NO}_{2}{ }^{-}$oxidation occurs close to the oxidation potential for ${ }^{\bullet} \mathrm{NO}$, has led to some controversy about what is measured in tissues by amperometry at a potential high enough to oxidise both species [29,32,33].

In the present study, we have determined the peak potentials of ${ }^{\bullet} \mathrm{NO}$ using square wave voltammetry by scanning the potential from +0.4 to $+1.0 \mathrm{~V}$ (scan rate $50 \mathrm{mV} / \mathrm{s}$ ). Fig. 2 shows typical voltammogram in oxygen free PBS

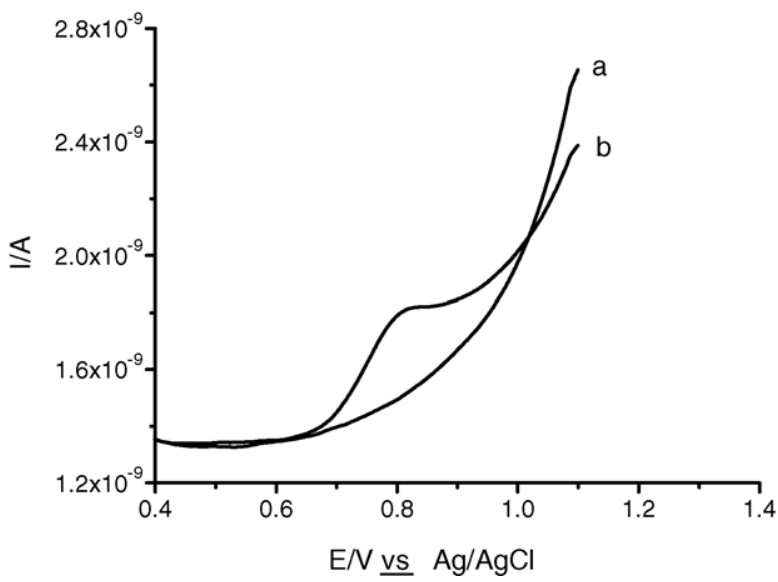

Fig. 2. Square wave voltammograms (SWV) of a deoxygenated PBS solution (a) and after addition of $13 \mu \mathrm{M} \bullet \mathrm{NO}$ prepared from $1.3 \mathrm{mM}$ DETA/NO solution (b) obtained with a Nafion/o-PD-modified carbon fiber microelectrode. Peak potential of $\bullet \mathrm{NO}:+0.80 \mathrm{~V}$.

solution (a), and after the addition of $13 \mu \mathrm{M} \cdot \mathrm{NO}$ prepared from DETA/NO (b). The oxidation peak potential of $-\mathrm{NO}$ (Epa) for the modified microelectrodes with Nafion and $o$-PD was $+0.80 \mathrm{~V}$ (average $+0.78 \pm 0.01 \mathrm{~V}$ versus $\mathrm{Ag} / \mathrm{AgCl}, 3 \mathrm{M}, n=13)$. Other authors using microelectrodes coated with nickel(II) tetrakis(3-methoxy-4hydroxyphenyl)porphyrin (TMHPP-Ni) and Nafion found oxidation peak potentials for ${ }^{\bullet} \mathrm{NO}$ to be $100 \mathrm{mV}$ lower, as compared to those reported here [13]. These differences may result from a different number of factors, such as the type of carbon fibers used, the Nafion coating procedures (temperature and number of coats), the catalytic effect of TMHPP-Ni and the electrochemical recording conditions.

In a different set of experiments, we have recorded amperometric currents by varying electrode potential between +0.2 to $+1.4 \mathrm{~V}$ for solutions of $100 \mu \mathrm{M}$ DETA/NO and $100 \mu \mathrm{M} \mathrm{NO}{ }_{2}^{-}$injected in the FIA system (Fig. 3). Two waves can be distinguished for ${ }^{\bullet} \mathrm{NO}$ oxidation, one from

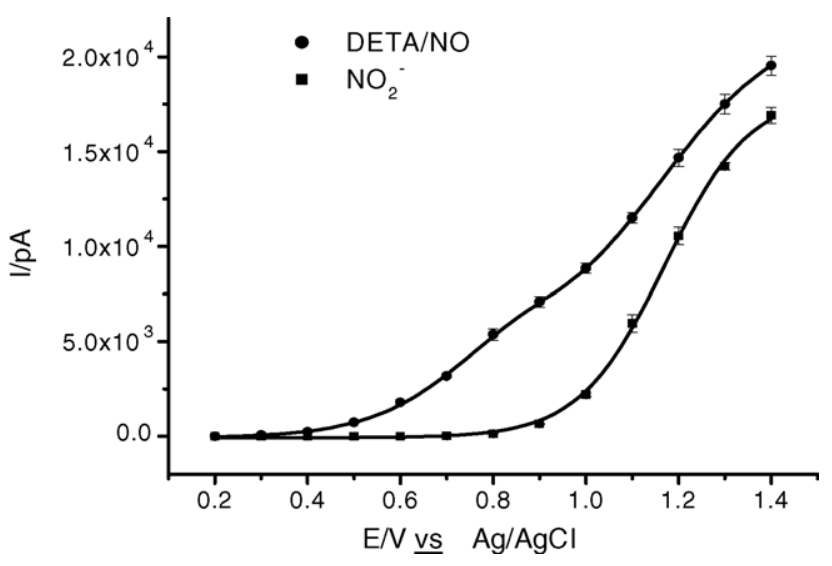

Fig. 3. Voltammograms of $1 \mu \mathrm{M} \bullet$ NO prepared from $100 \mu \mathrm{M}$ DETA/NO and $100 \mu \mathrm{M} \mathrm{NO}_{2}{ }^{-}$solutions injected in the flow injection analysis system using PBS as carrier solution. Currents were recorded with a Nafion/o-PD microelectrode between +0.2 to $+1.4 \mathrm{~V}$. 

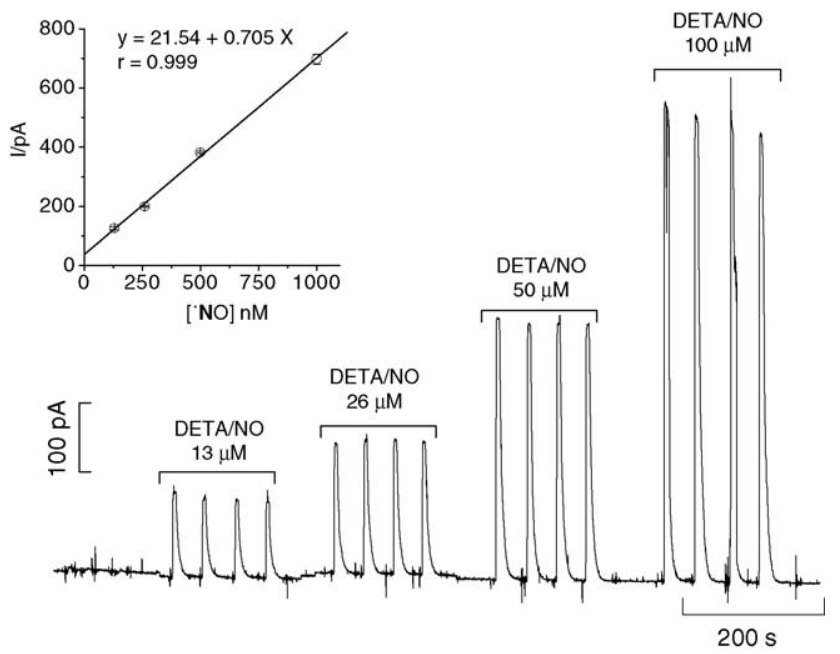

Fig. 4. Flow injection analysis amperogram at a constant potential of $+0.9 \mathrm{~V}$ vs. $\mathrm{Ag} / \mathrm{AgCl}$ of DETA/NO solutions ranging from 13 to $100 \mu \mathrm{M}(0.13-1 \mu \mathrm{M}$ -NO) prepared using a Nafion/o-PD microelectrode. The inset shows the calibration curve.

+0.4 to $+0.9 \mathrm{~V}$ (half-wave potential, $+0.8 \mathrm{~V}$ ) and a second from +0.9 to $+1.4 \mathrm{~V}$ (half-wave potential, $+1.2 \mathrm{~V}$ ). $\mathrm{NO}_{2}{ }^{-}$ oxidation resulted in only one wave from +0.9 to $+1.4 \mathrm{~V}$ (half-wave potential, $+1.2 \mathrm{~V}$ ). This is in accordance with the accepted reaction mechanism of ${ }^{\bullet} \mathrm{NO}$ oxidation on solid surfaces [29]; the first wave is the result of the ${ }^{\bullet} \mathrm{NO}$ oxidation to $\mathrm{NO}_{2}{ }^{-}$, whilst the second reflects its further oxidation to $\mathrm{NO}_{3}{ }^{-}$. Thus, we have selected $+0.9 \mathrm{~V}$ as the optimal potential for amperometric measurements of ${ }^{\bullet} \mathrm{NO}$ oxidation currents with modified carbon fiber microelectrodes.

\subsubsection{Sensitivity and detection limit}

The calibrations of the microelectrodes should be performed in conditions similar to those of the experimental perfusion system. Therefore, we have used a FIA system to reproduce hydrodynamic flow conditions and allowed recording transient currents in a high reproducible way.

Calibrations were performed for different ${ }^{\bullet} \mathrm{NO}$ concentrations ranging from $130 \mathrm{nM}$ to $1 \mu \mathrm{M}$ prepared from DETA/NO solutions (Fig. 4). Each ${ }^{\bullet} \mathrm{NO}$ concentration was repeatedly injected. Sensitivity was calculated from the slope of the linear regression for peak current amplitude versus concentration of ${ }^{\bullet} \mathrm{NO}$. The average sensitivity was $954 \pm 217 \mathrm{pA} / \mu \mathrm{M} \bullet \mathrm{NO}$; $(n=6)$. The calibrations performed in the FIA system were also reproduced using classical amperometry (Fig. 5).

The limit of detection (LOD) was determined by calibrating microelectrodes with ${ }^{\bullet} \mathrm{NO}$ standard solutions injected repeatedly in the FIA system in the concentration range of 13-100 nM prepared from DETA/NO solutions (Fig. 6). Microelectrodes average detection limit was $6 \pm 2 \mathrm{nM} \bullet \mathrm{NO}$ $(n=4)$. This factor is affected by the sensitivity of the ${ }^{\bullet} \mathrm{NO}$ microelectrode as well as the instrument performance, and this might help explain the improved detection limit of our microelectrodes when compared with those fabricated by others using carbon fiber electrodes modified with Nafion and $o$-PD

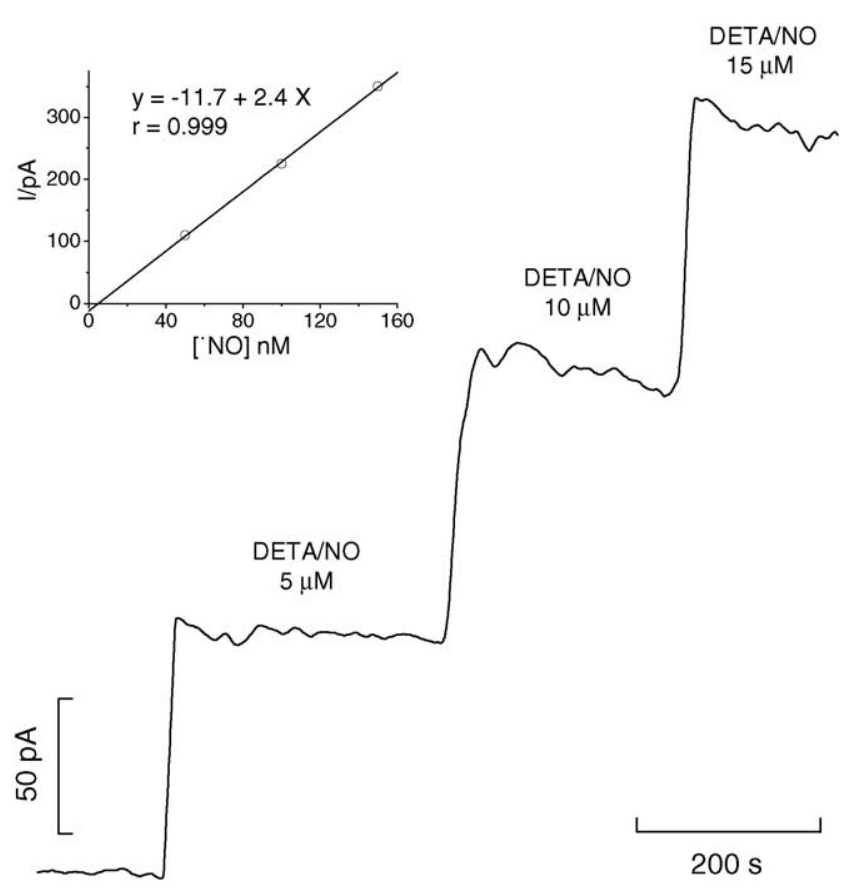

Fig. 5. Amperometric response at $+0.9 \mathrm{~V}$ vs. $\mathrm{AgAgCl}$ of a Nafion/o-PD microelectrode to successive additions of 5, 10 and $15 \mu \mathrm{M}$ DETA/NO (50, 100 and $150 \mathrm{nM}{ }^{\bullet} \mathrm{NO}$ ) to deoxygenated PBS solution. The resulting calibration curve is shown inset.

$[14,34,35]$. The higher sensitivity could also be attributed to the hidrophobicity of $o$-PD-based polymers, which favoured partitioning of $\bullet \mathrm{NO}$ from aqueous solution $[34,36]$.

\subsubsection{Selectivity}

This parameter is crucial for reliable $\bullet \mathrm{NO}$ measurements in tissues due to its high oxidation potential [37]. Thus, in the amperometric mode, we must be careful with other electroac-

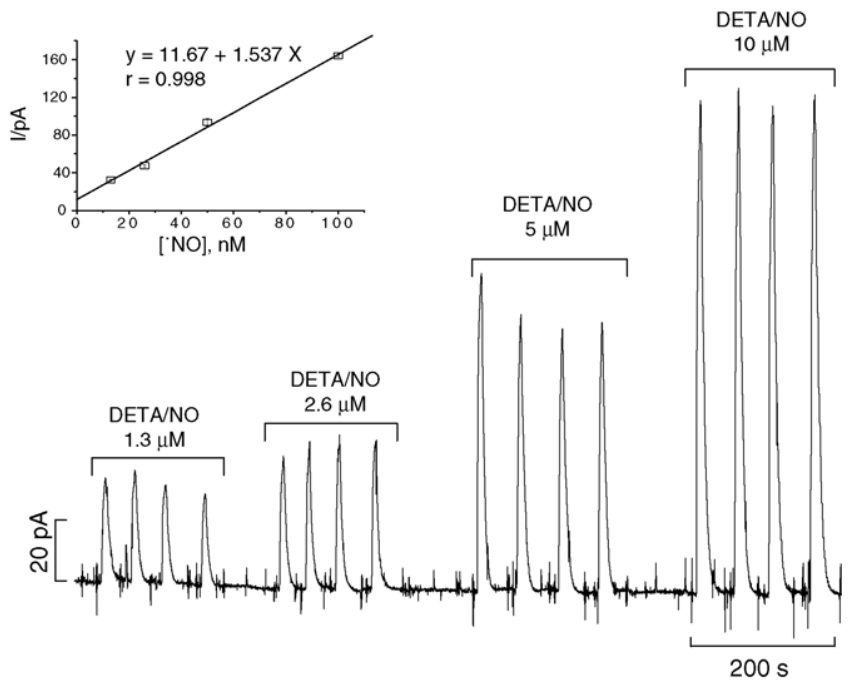

Fig. 6. Flow injection analysis amperogram of $\bullet$ NO solutions ranging from 1.3 to $10 \mu \mathrm{M}$ DETA/NO $(13-100 \mathrm{nM} \cdot \mathrm{NO})$. The calculated limit of detection of the Nafion/o-PD microelectrode was $8 \mathrm{nM} \bullet \mathrm{NO}$, according to the calibration curve shown in inset figure. 
Table 1

-NO selectivity ratios for the Nafion/o-PD microelectrodes against various interfering compounds

\begin{tabular}{lll}
\hline Compound & Selectivity ratio $($ mean \pm S.E.M.) & $n$ \\
\hline Nitrite & $780: 1 \pm 84$ & 6 \\
Ascorbic acid & $750: 1 \pm 187$ & 6 \\
Dopamine & $18: 1 \pm 2$ & 6 \\
5 -HT & $39: 1 \pm 9$ & 6 \\
Tyrosine & $149: 1 \pm 37$ & 5 \\
$\mathrm{~N}_{x} \mathrm{O}_{y}$ & $245: 1 \pm 96$ & 4 \\
$\mathrm{ONOO}^{-}$ & $2119: 1 \pm 1280$ & 4 \\
$\mathrm{H}_{2} \mathrm{O}_{2}$ & $>10000: 1$ & 5 \\
L-Glu & $>10000: 1$ & 6 \\
L-Arg & $>10000: 1$ & 6 \\
NMDA & $>10000: 1$ & 6 \\
\hline
\end{tabular}

tive species present in the brain, such as catechols, indoles and ascorbate, which oxidise well below the potential of $\bullet$ NO (between +0.1 and $+0.5 \mathrm{~V}$ ) [25].

Using amperometry $(+0.9 \mathrm{~V}$ versus $\mathrm{Ag} / \mathrm{AgCl})$, we have assessed the selectivity of the microelectrodes against a series of potential interfering compounds. Table 1 shows the selectivity ratios ${ }^{\bullet} \mathrm{NO}$ :interferent, calculated on a molar basis for the tested interferents that produced a measurable current. The data suggest that one layer of Nafion dried at $170^{\circ} \mathrm{C}$ conferred high selectivity against anions. However, the selectivity against positively charged molecules was much lower indicating that the $o$-PD film is not very effective as a molecular filter for dopamine and 5-HT on these carbon surfaces. Tyrosine, another potential interferent in the brain, was also tested and the data showed good selectivity for this compound. $\mathrm{ONOO}^{-}$was tested using $\mathrm{NaOH}$ as a carrier, because under $\mathrm{pH} 7.4$, it has a very short half life $(\approx 1 \mathrm{~s})$. Compounds used as stimulus for ${ }^{\bullet} \mathrm{NO}$ production did not give any oxidation current for concentrations up to $0.1 \mathrm{mM}$ for NMDA and $1 \mathrm{mM}$ for L-arginine and L-glutamate.

\subsubsection{Response time}

To evaluate the influence of diffusion rate of $\bullet$ NO crossing the coatings, a bare microelectrode was used as a control. The average half-maximal response time $\left(t_{50 \%}\right)$ at a bare carbon fiber microelectrode after the injection of $26 \mu \mathrm{M}$ DETA/NO solution was $0.95 \pm 0.15 \mathrm{~s}(n=4)$. On average, microelectrodes coated with Nafion/o-PD exhibited half-maximal response times of $1.90 \pm 0.1 \mathrm{~s}(n=9)$, which is ca. $1 \mathrm{~s}$ higher when compared with bare microelectrodes. Thus, the response time of the polymer-modified microelectrode to $t_{50 \%}$ is $1 \mathrm{~s}$.

These values are higher than previously reported [14]. However, these determinations were strongly affected by the flow injection system used namely the flow rate, concentration tested and tube diameter of the system and these longer response times may be due to dispersion of the FIA system [38]. In addition, the FCV pre-treatment is known to enhance the active surface area of carbon fiber microelectrodes but decreases their response times [39].
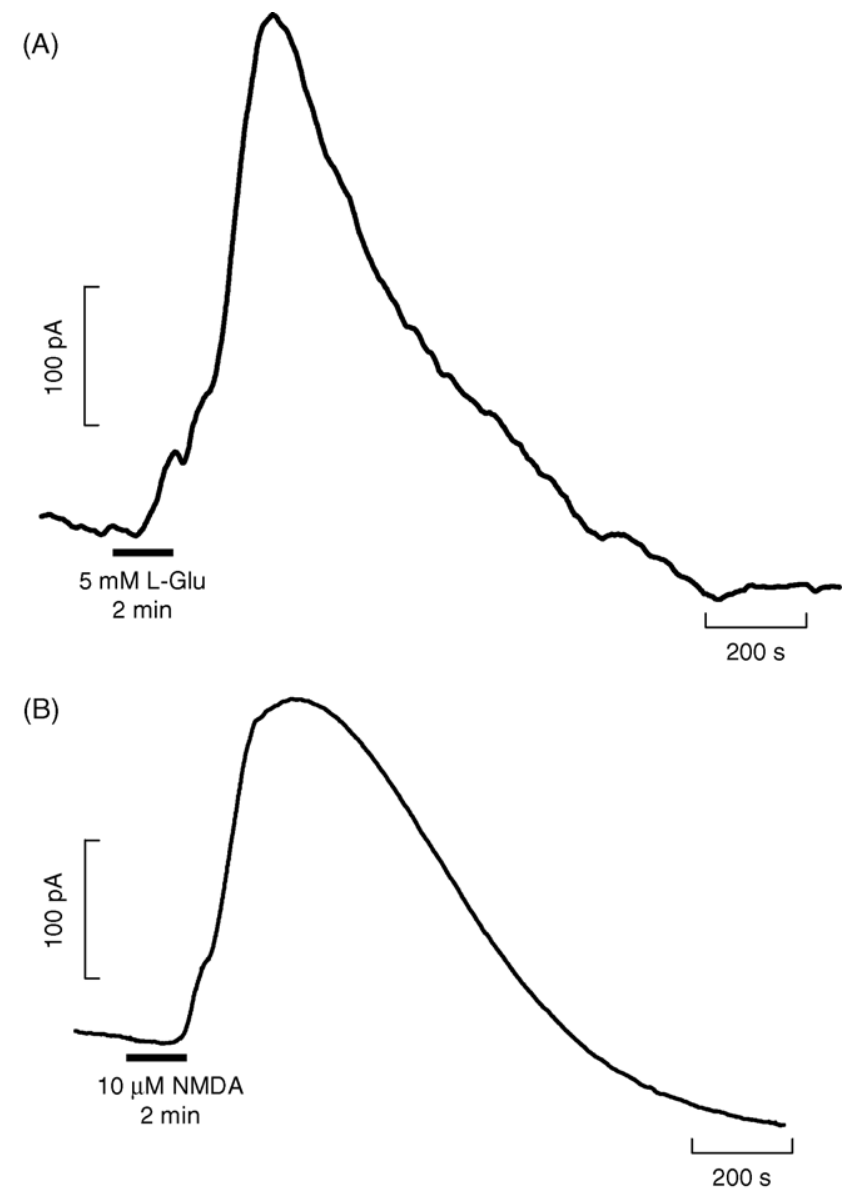

Fig. 7. L-glutamate-induced efflux (current/time profile) of $\bullet$ NO recorded in the CA1 region of the hippocampal slice following a 2 min perfusion of $5 \mathrm{mM}$ L-glutamate (A) and $10 \mu \mathrm{M}$ NMDA (B).

\section{3. ${ }^{\bullet} \mathrm{NO}$ detection in brain hippocampal slices}

Fig. 7A shows a typical in situ amperometric recording of -NO production in hippocampal slices using the polymermodified carbon fiber microelectrodes. The perfusion of $5 \mathrm{mM} \mathrm{L}$-glutamate for 2 min evoked a transient increase in -NO current, measured with the microelectrode placed in the CA1 subregion. The maximum current was reached in 5 min, whereas the decay to baseline was characterized by a time constant of $348 \mathrm{~s}$, as calculated by a non-linear regression analysis $(r=0.992)$ of the signal decay using an exponential first order equation (average: $430 \pm 72 \mathrm{~s} ; n=4$ ). The total charge of the pulse calculated by integration of the current/time profile was $94 \mathrm{nC}$ (average: $95 \pm 8 \mathrm{nC} ; n=4$ ).

In another set of experiments, a L-glutamate stimulus was replaced by perfusion with $10 \mu \mathrm{M}$ NMDA, during 2 min (Fig. 7B). Under these stimulation conditions, the ${ }^{\bullet} \mathrm{NO}$ production was characterized by a total charge of $128 \mathrm{nC}$ (average: $197 \pm 38 \mathrm{nC} ; n=3$ ). The signal increase reached the maximum current in $4.2 \mathrm{~min}$, and an exponential decay with a time constant of $340 \mathrm{~s}(r=0.996)$ (average: $509 \pm 222 \mathrm{~s}$; $n=3)$. 
It is apparent that stimulation with $10 \mu \mathrm{M}$, NMDA promotes a higher overall production of ${ }^{\bullet} \mathrm{NO}$ than $5 \mathrm{mM} \mathrm{L-}$ glutamate. Nevertheless, when decay time constants are determined, differences are not statistically significant $(P>0.05)$, as measured by a Student's $t$-test.

Thus, on basis of decay time constants, and as would be expected for a selective measurement of $\bullet \mathrm{NO}$, the concentration dynamics of $\bullet \mathrm{NO}$ produced either by stimulation with L-glutamate or NMDA, follows a similar pattern.

\section{Conclusions}

The present work supports the hypothesis that Nafion/oPD-modified carbon fiber microelectrodes, are capable of sensitive (sensitivity $=954 \pm 217 \mathrm{pA} / \mu \mathrm{M} \quad \mathrm{NO}$; $\left.\mathrm{LOD}=6 \pm 2 \mathrm{nM}{ }^{\bullet} \mathrm{NO}\right)$, rapid $\left(t_{50 \%} \approx 1 \mathrm{~s}\right)$ and reproducible measures of $\bullet \mathrm{NO} . \mathrm{NO}_{2}{ }^{-}$is not a major interferent for detection of ${ }^{\bullet} \mathrm{NO}$. The in vitro brain slice studies support the notion that the microelectrodes can be used to study ${ }^{\bullet} \mathrm{NO}$ signalling in brain slices. The signals recorded gain a high physiological relevance if one consider the role of $\bullet \mathrm{NO}$ in signalling pathways underlying memory and learning processes in hippocampus.

\section{Acknowledgements}

This work was supported by a Grant (POCTI/2001/ BCI/42365) from Fundação Ciência e Tecnologia and FEDER to J.L.Greg Gerhardt's work was supported by USPHS grants MH01245 and MH58414.

\section{References}

[1] L.J. Ignarro, G.M. Buga, K.S. Wood, R.E. Byrns, G. Chaudhuri, Proc. Natl. Acad. Sci. U.S.A. 84 (1987) 9265.

[2] R.M. Palmer, A.G. Ferrige, S. Moncada, Nature 327 (1987) 524.

[3] S. Moncada, R.M. Palmer, E.A. Higgs, Biochem. Pharmacol. 38 (1989) 1709.

[4] J. Garthwaite, C.L. Boulton, Annu. Rev. Physiol. 57 (1995) 683.

[5] V.L. Dawson, T.M. Dawson, Prog. Brain Res. 118 (1998) 215.

[6] J.A. Gally, P.R. Montague, G.N. Reeke Jr., G.M. Edelman, Proc. Natl. Acad. Sci. U.S.A. 87 (1990) 3547.

[7] S. Archer, FASEB J. 7 (1993) 349.
[8] F.L. Kiechle, T. Malinski, Am. J. Clin. Pathol. 100 (1993) 567.

[9] Z.H. Taha, Talanta 61 (2003) 3.

[10] J. Sun, X.J. Zhang, M. Broderick, H. Fein, Sensors 3 (2003) 276.

[11] D.C. Yao, A.G. Vlessidis, N.P. Evmiridis, A. Evangelou, S. Karkabounas, S. Tsampalas, Anal. Chim. Acta 458 (2002) 281.

[12] K.M. Mitchell, E.K. Michaelis, Electroanalysis 10 (1998) 81.

[13] T. Malinski, Z. Taha, Nature 358 (1992) 676.

[14] M.N. Friedemann, S.W. Robinson, G.A. Gerhardt, Anal. Chem. 68 (1996) 2621.

[15] J.K. Park, P.H. Tran, J.K.T. Chao, R. Ghodadra, R. Rangarajan, N.V. Thakor, Biosens. Bioelectron. 13 (1998) 1187.

[16] F. Bedioui, N. Villeneuve, Electroanalysis 15 (2003) 5.

[17] N. Diab, W. Schuhmann, Electrochim. Acta 47 (2001) 265.

[18] A. Ciszewski, G. Milczarek, Talanta 61 (2003) 11.

[19] G.A. Gerhardt, A.F. Oke, G. Nagy, B. Moghaddam, R.N. Adams, Brain Res. 290 (1984) 95.

[20] M.P. Brazell, R.J. Kasser, K.J. Renner, J. Feng, B. Moghaddam, R.N. Adams, J. Neurosci. Methods 22 (1987) 172.

[21] J.S. Beckman, J. Chen, H. Ischiropoulos, J.P. Crow, Methods Enzymol. 233 (1994) 229

[22] R.M. Barbosa, A.M. Silva, A.R. Tome, J.A. Stamford, R.M. Santos, L.M. Rosario, J. Physiol. 510 (1998) 135.

[23] A. Ledo, R.M. Barbosa, J. Frade, J. Laranjinha, Methods Enzymol. 359 (2002) 111

[24] G.A. Gerhardt, A.F. Hoffman, J. Neurosci. Methods 109 (2001) 13.

[25] J.A. Stamford, F. Crespi, C.A. Mardsen, in: J.A. Stamford (Ed.), Monitoring Neuronal Activity, The Practical Approach Series, IRL Press at Oxford University Press, Oxford, 1992, p. 113.

[26] X.J. Zhang, L. Cardosa, M. Broderick, H. Fein, I.R. Davies, Electroanalysis $12(2000) 425$.

[27] L.K. Keefer, R.W. Nims, K.M. Davies, D.A. Wink, Methods Enzymol. 268 (1996) 281.

[28] A.L. Fitzhugh, L.K. Keefer, Free Radic. Biol. Med. 28 (2000) 1463.

[29] T. Malinski, L. Czuchajowsi, in: M. Feelish, J. Stamler (Eds.), Methods in Nitric Oxide Research, Wiley, Chichester, 1996, p. 19.

[30] S. Moncada, R.M. Palmer, E.A. Higgs, Biochem. Soc. Trans. 17 (1989) 642.

[31] J. Wood, J. Garthwaite, Neuropharmacology 33 (1994) 1235.

[32] F. Crespi, M. Campagnola, A. Neudeck, K. McMillan, Z. Rossetti, A. Pastorino, U. Garbin, A. Fratta-Pasini, A. Reggiani, G. Gaviraghi, L. Cominacini, J. Neurosci. Methods 109 (2001) 59.

[33] J.A. Stamford, in: A. Schurr, B.M. Rigor (Eds.), Brain Slices in Basic and Clinical Research, CRC Press, Boca Raton, FL, 1995, p. 66.

[34] M. Pontie, F. Bedioui, J. Devynck, Electroanalysis 11 (1999) 845.

[35] M. Pontie, C. Gobin, T. Pauporte, F. Bedioui, J. Devynck, Anal. Chim. Acta 411 (2000) 175.

[36] L.J. Murphy, Anal. Chem. 70 (1998) 2928.

[37] A. Brunet, A. Pailleret, M.A. Devynck, J. Devynck, F. Bedioui, Talanta 61 (2003) 53.

[38] E.W. Kristensen, R.L. Wilson, R.M. Wightman, Anal. Chem. 58 (1986) 986.

[39] F.G. Gonon, M. Buda, J. Neurosci. 14 (1985) 765. 